
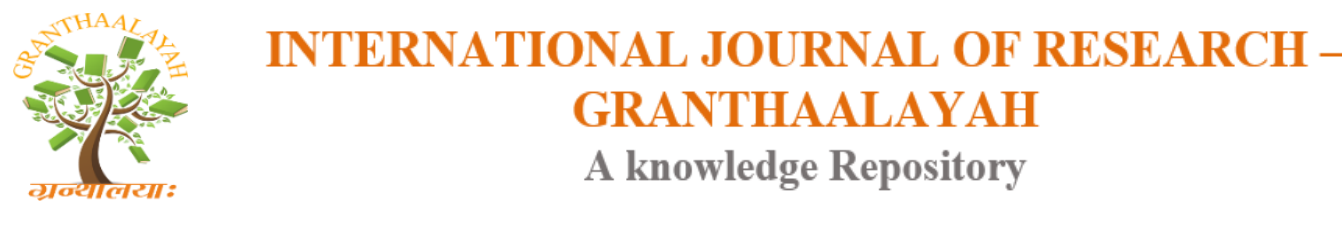

Social

\title{
ASSESSMENT OF THE EFFECTIVENESS OF SCHOOL GUIDANCE SERVICES AS PERCEIVED BY SECONDARY SCHOOL PRINCIPALS IN EDO STATE, NIGERIA
}

\author{
Ehigbor, Beatrice Omozele Ph.D ${ }^{1}$, Akinlosotu, Nathaniel Toyosi ${ }^{2}$ \\ ${ }^{1}$ Department of Guidance and Counselling, Faculty of Education, Ambrose Alli University, \\ Ekpoma, Edo State, Nigeria \\ ${ }^{2}$ Department of Economics, Faculty of Social Sciences, Ambrose Alli University, Ekpoma, Edo \\ State, Nigeria
}

\begin{abstract}
The study investigated the effectiveness of school guidance services as perceived by principals in Edo State, Nigeria. The study sought to examine secondary school principals' perception on the effectiveness of guidance services (orientation, appraisal, information and counselling services) and determine gender and school location differences in principals' perception of the effectiveness of counselling services in schools. The descriptive survey design was adopted for the study. A sample of 36 schools (1 rural and 1 urban) were drawn from public senior secondary schools in the study area using purposive random sampling. The instrument used for the collection of data was a self-developed questionnaire titled: "School Guidance Services Effectiveness Questionnaire (SOGSEQ)". The construct validity was ascertained by the Principal Component Analysis (PCA) while the Cronbach reliability alpha of the questionnaire yielded an overall index of 0.84 . The descriptive statistics such as mean $\left(\mathrm{X}_{\overline{\mathrm{T}}}\right.$ and standard deviation (S.D) was used to analyze the research question 1 while the t-test for independent sample means was used to test the hypothesis at 0.05 alpha level. Results from the analysis showed that principals perceived orientation services to be the only effective guidance service in secondary schools in Edo State. Result further showed that there is a significant difference between rural and urban principals in their perception on the effectiveness of school guidance services (appraisal, information and counselling services) in secondary schools in Edo State. It is recommended that guidance counsellors in the secondary schools should realize that their guidance services should be such that will enable them to meet the needs of learners in schools. For this to be achieved, school heads, teachers, parents and the government must also be actively involved in providing their support for the delivery of the services when necessary.
\end{abstract}

Keywords: Guidance Services; Principals; Secondary Schools.

Cite This Article: Ehigbor, Beatrice Omozele Ph. D, and Akinlosotu, Nathaniel Toyosi. (2018). "ASSESSMENT OF THE EFFECTIVENESS OF SCHOOL GUIDANCE SERVICES AS PERCEIVED BY SECONDARY SCHOOL PRINCIPALS IN EDO STATE, NIGERIA." 
International Journal of Research - Granthaalayah, 6(9), 105-115. https://doi.org/10.5281/zenodo.1436773.

\section{Introduction}

School guidance programme and services is the main domain of trained school counsellors and anything that has to do with this service must be performed by guidance counsellors. School guidance counsellors are expected to devote a great deal of his/her time to counseling, just in the same way that a teacher in a school is employed to guide and stimulate students' learning, so also is a school counsellor employed to use his/her skills to assist students, to resolve their everyday problems or conflicts which have been, or may be, obstructing their search for learning (Nwaokolo, 2006). In other to solve some of these challenges, some professional services have therefore been introduced under the school guidance programme to assist students overcome the challenges they experience at home and at school. These services are known as 'school guidance services'.

Adomeh (2006) referred to school guidance services as specialized services carried out by trained guidance counsellors in addressing or meeting specific needs of students. He identified nine (9) school guidance services to include: orientation, research and follow up, planning and placement, appraisal, information, referral, consultation, counselling and evaluation services. These services explain some vital areas of school guidance counsellors' roles and functions in the school system. Various roles have been suggested for school guidance counsellors in the past. Shertzer and Stone (2009), for example, stated that counsellors have functioned in the roles of: (i) quasi-administrators who act in the absence of principals; they assign teachers and students to classes and are responsible for extracurricular activities; (ii) generalises who have no specific function but have priority placed on orientation, group guidance, a developer of cumulative records as well as a testing expert; (iii) specialists who give counselling priority over all other activities; (iv) change agents or (v) psychological educators.

Wrenn (2002) proposed a statement of the functions of guidance counsellors regardless of setting is: a) to provide a relationship between counsellor and counsellee, the most prominent quality of which is that of mutual trust of each in the other, b) to provide alternatives in self-understanding and in the courses of action open to the counsellee, c) to provide for some degree of intervention with the situation in which the counsellee finds himself (or herself) and with "important others" in the counsellee's immediate life, d) to provide leadership in developing a healthy psychological environment for clients, and e) to provide for the improvement of the, counselling process through constant individual self-criticism and (for some counsellors) extensive attention to improvement of process through research. Unfortunately the practice of these services in most schools in Edo State is not effective. The programme is not encouraging at the secondary school level and even at the university level. Abiri (2006) argued that if the society is not to be plaque by a band/group of disgruntled, frustrated and unrealistic individuals, it is desirable that adequate guidance services be provided, to enhance the educational system.

In other to ensure that guidance and counselling wears a national outlook, the Federal Republic of Nigeria (2013) made it clear that guidance services should be rendered to students in schools. This is to fulfill the Nigerian government's policy and as a way of implementing the policy statement, professional guidance counsellors are posted to virtually all the post-primary schools in Nigeria. 
Although, the policy provision has been encouraging, the implementation of the same has been so challenging. For instance, it has been alleged that most secondary schools in Ekpoma metropolis do not have trained guidance counsellors while a few schools just have para-professional counsellors who are teachers or head teachers appointed by the principal or school to take up the roles of guidance counsellors in the school.

Previous studies on effectiveness of school guidance programme and services abound in literature. Aluede and Imonike (2002) surveyed secondary school students to determine how they perceived the effectiveness and responsibilities of the school guidance counsellors. Results indicated that although students could readily identify roles of the school guidance counsellors; there was a lack of consensus in their perception on the effectiveness of their guidance services. Students saw the role of the school guidance counsellors as mostly involving academic counselling activities while some perceived it as providing career information and advice on disciplinary matters. Based on the available research evident, it appears that many students do not have a full understanding of what guidance services are all about. Hence, investigating students' perception on the effectiveness of guidance services could help in the development of guidance services for a more meaningful educational system.

Ogunsanmi (2011) investigated the awareness of primary school teachers toward the effectiveness of guidance and counseling services in primary schools in Nigeria. The purpose was to find out the awareness of teachers in primary schools in Nigerian toward the effectiveness of each of the guidance counselling services (information, counselling, co-ordination, consultation, planning, orientation, placement, follow-up, referral, appraisal service) with a view to understanding their level of knowledge of the services when fully introduced into the primary school system in Nigeria. A research hypothesis was postulated and tested using t-test analysis. Results revealed that many of the teachers were aware of the effectiveness of guidance and counseling services in primary schools.

Wrenn (2002) investigated the effectiveness of guidance and counseling services and their functions from students' perspective and found that the function of the counsellor as perceived by students in any setting are: a) to provide a relationship between counsellor and counsellee, b) to provide alternatives in self-understanding and in the courses of action open to the counsellee, c) to provide for some degree of intervention with the situation in which the counsellee finds himself (or herself) and with "important others" in the counsellee's immediate life, d) to provide leadership in developing a healthy psychological environment for. . clients, and finally, e) to provide for the improvement of the, counselling process through constant individual self-criticism and (for some counsellors) extensive attention to improvement of process through research.

Nwoye (2003) found out from a national survey that school counsellors were responsible to the principals, teachers, students, parents, and the community in certain ways. From his survey on students' perception of guidance counselling service, some counsellors' responsibilities he listed are that they: (i) Organise orientation to help new students from primary to secondary school adjust to the new environment; (ii) Define and interpret the objectives of the guidance programme to the principal, teachers, students, parents and members of the community; (iii) Identify guidance needs of students and keep teachers informed of developments which may have bearing on classroom situations; (iv) assist teachers in providing group guidance experiences to students through talks, 
club and classroom activities; (v) Coordinate the accumulation, development and effective use of meaningful data through interviews etc. for the effective implementation of the continuous assessment procedures; (vi) Help principal to provide information to parents about school policies etc; (vii) Assist parents to have a realistic perception of their children's attitudes, aptitude, interests etc; (viii) Collect and disseminate to parents information concerning careers and opportunities for further education, training and curricular offerings etc.

Various roles and functions have been suggested for school counsellors in the past. Shertzer and Stone (1990) found that students' perceived counsellors' are (i) quasi-administrators who act in the absence of principals; they assign teachers and students to classes and are responsible for extracurricular activities; (ii) general administrators who have no specific function but have priority placed on orientation, group guidance, a developer of cumulative records as well as a testing expert; (iii) specialists who give counselling priority over all other activities; (iv) change agents or (v) psychological educators.

Adepoju (2005) in his study conducted among 315 students in public schools in Alimosho area of Lagos State found that majority $(67.2 \%)$ of the female secondary students viewed counseling as advice-giving (a 2 Medway, 2007). However, the authors of these studies noted that their participants reported having limited knowledge of school counselling services. Farrell et al. (2005) and Dimakos (2006) found that the majority of the female students interviewed, valued the services of their school counsellors and wanted more access to such professionals. Cooper et al. (2005) conducted two separate studies that surveyed secondary school students' attitudes and views toward school counselling services. In the first study, some male students were asked to rate how important they felt it was for there to be a school counsellor in their school. Forty percent of participants indicated they felt having a school counsellor was essential while only $7 \%$ felt a school counsellor was not essential at all. Further evidence was found in Cooper et al.'s second study in which participants had, on average, high levels of agreement that Counseling services can make a difference in their lives as students and influence the educational system.

Aluede and Imonikhe (2002) surveyed secondary school teachers and their students from various schools in rural and urban areas to determine how they perceived the responsibilities of school counsellors. Results indicated that although students could readily identify roles of the school counsellors, there was a lack of consensus between students from rural schools and those from urban schools. Students saw the roles of school counsellors as mostly involving academic counselling activities while those from urban, viewed the school counsellor as someone to provide career information to students and advise them on disciplinary matters.

Monteiro-Leitner, Asner-Self, Milde, Leitner, and Skelton (2006) found that the perceptions of rural and urban school students towards counsellors and their various services in schools (e.g., consulting on referrals, individual/group Counseling) were very similar and significantly indifferent. However, the amount of time that they perceived should be devoted to specific duties varied between the participant groups. Students from rural schools suggested that school counsellors should spend 4.4 hours per week on Individual Education Plans (IEPs) and 2.32 hours per week on administrative duties (e.g., supervision), while students in urban schools indicated that they should spend 18.5 hours per week on counselling and professional development of students. Beesley (2004) surveyed a group of students in rural and urban schools regarding their 
perception of the effectiveness of school counselling services. The results indicated that students were generally satisfied with the services of counsellors, but the degree of satisfaction varied by school location and depended on the specific service area provided by the school counsellor (e.g.,career Counseling, community referral).

Langford (2006) studied students' perceptions of the responsibilities of the school counsellors. She compared perceptions from several elementary and high school students from schools in the surburb (urban) and outskirt (rural) area of Melborne, Australia. A group of 212 students were surveyed to determine how much knowledge they had regarding the responsibilities and functions of the school counsellor as recommended by the American School Counselor Association (ASCA) National Model. The result shows that students' perception of counsellors' responsibilities and functions differ by school location. Results also suggested that the more highly the students regarded the responsibilities of the school counsellor in general, the more likely they were to report a willingness to collaborate with school counsellors in their future practice.

Agi (2013) investigated the status of guidance services in some Secondary schools in Rivers State. Out of the two hundred and fifty (250) public schools in Port Harcourt, only twenty (20) have at least a practicing counsellor. Fourteen schools with practicing counsellors were sampled in this study. The two Federal Government and University Demonstration Schools in Port Harcourt were also included in the study. Data was collected through the administration of a questionnaire on guidance services. Data analysis revealed Guidance and Counselling services in Rivers State are faced with many obstacles which jeopardize effective delivery of the services, thereby resulting in educational wastage instead of the expected quality outcome. Funds for provision of basic guidance services are lacking. Most of the vital counselling services needed for quality education are the least regularly performed in schools e.g. use of psychological tests and keeping of cumulative record folders. Furthermore, students' perception of the effectiveness of school guidance services differed significantly by school location.

Chireshe (2006) assessed the effectiveness of the Zimbabwean secondary school guidance and counselling services from school counsellors' and students' perspective. The survey method and self-constructed questionnaire was used in the study. Three hundred and fourteen school counsellors and 636 students participated in this study. The SAS/STAT (version 9.1) was used to analyse the data. The one way and combined two way frequency tables were calculated while ratios were used to establish the relative rating of each item. Chi-square (X2) tests were further used to test the hypotheses. Based on the result, the study revealed that majority of both school counsellors and students viewed the school guidance and counselling services as beneficial and school counsellors as effectively playing their role. However, they asserted that effectiveness of the Zimbabwean secondary school guidance and counselling services was negatively affected by lack of resources and training in guidance and counselling and non-counselling duties performed by school counsellors. Students' perception of the effectiveness of school guidance services did not differ significantly by school location.

Printah (2014) assessed the guidance and counselling programme in Mzilikazi District situatedof the Bulawayo Metropolitan Province. The study revealed that $80 \%$ of the secondary schools in Mzilikazi District had not yet complied with the Ministry of Primary and Secondary Education on the implementation of the programme. Lack of qualified teachers, stationary, books and relevant 
facilities like counselling rooms were found to be major barriers inhibiting the implementation of Guidance and Counselling services. The findings also revealed that most of the students are ignorant of the existence of such services which could be the major cause of high rates of delinquency, truancy, alcohol and drug abuse and teenage pregnancies. Students' perception of the effectiveness of school guidance services did not differ significantly by school location.

From the foregoing, all the recent studies on school guidance programme and effectiveness of school guidance counsellors were carried out beyond Edo State while Aluede and Imonikhe (2002) who carried out their study in Edo State, drew their conclusion based on students' perceptions of the guidance services in schools. Consequently, a knowledge gap exists on the effectiveness of school guidance services as perceived by secondary school principals in Edo State. Hence, a knowledge gap exists. To fill this gap, this study sought to provide answer to the research questions:

1) What are principals' perceptions on the effectiveness of school guidance services in senior secondary schools in Edo State?

2) Do school location differences exist in principals' perceptions on the effectiveness of school guidance services in senior secondary schools in Edo State?

\section{Hypothesis}

The hypothesis formulated and tested in the study is given below:

1) There is no significant difference between rural and urban principals in their perceptions on the effectiveness of school guidance services in secondary schools in Edo State.

\section{Methods}

The descriptive research design was adopted in this study. The population covered all the 310 principals in public Senior Secondary Schools in the eighteen (18) local government areas in Edo State. From each local government area, two (2) schools (one, rural and one urban school) with (a functional guidance and counselling units and trainee counsellors or teacher-counsellors) were selected by purposive sampling technique. This gave a total sample of 36 principals for the study. A 12-item questionnaire titled: "School Guidance Services Effectiveness Questionnaire (SOGSEQ) was developed by the researchers was used for the collection of data.

The construct validity of the study was ensured by the Principal Component Analysis (PCA). Using the PCA, a total of 23-item was rotated using varimax rotation technique. After rotation, four components were extracted for all items with an Eigen value greater than 1 . The four components were named to be orientation, appraisal, information and counselling services. The name was informed by what the item(s) with the higher relative contribution of the item on the factor loading of each item per component. The Cronbach reliability alpha was used to determine the reliability index of the instrument. The instrument yielded an overall index of 0.84 . Descriptive statistics such as mean $(\overline{\mathrm{X}})$ and standard deviation (S.D) was used to analyze the research question 1 while the t-test for independent sample means was used to test the hypothesis at 0.05 level of significance. 


\section{Results}

The results of the analysis of the hypotheses are presented below.

Research Question 1: What are students' perceptions on the effectiveness of orientation services in secondary schools in Ekpoma?

Table 1: Mean score $(\overline{\mathrm{X}})$ and Standard Deviation (S.D) on students' perceptions on the effectiveness of orientation services in secondary schools in Ekpoma

\begin{tabular}{|c|c|c|c|c|}
\hline \multirow{2}{*}{$\begin{array}{l}\text { Item } \\
\text { no }\end{array}$} & \multirow[t]{2}{*}{ Items } & \multicolumn{3}{|l|}{$\mathrm{N}=36$} \\
\hline & & $\overline{\mathrm{X}}$ & S.D & Remark \\
\hline & Orientation services & & & \\
\hline & $\begin{array}{l}\text { Providing newly admitted students with orientation about } \\
\text { the school to prepare them for the school system }\end{array}$ & $2.58 *$ & .985 & Effective \\
\hline & $\begin{array}{l}\text { Providing orientation service to students enable } \\
\text { understand the school community better }\end{array}$ & $2.55^{*}$ & .896 & Effective \\
\hline & $\begin{array}{l}\text { Providing students with orientation needed to enjoy their } \\
\text { relationship with peers }\end{array}$ & $2.54^{*}$ & .947 & Effective \\
\hline & Overall mean $=2.56^{*}$ & & & \\
\hline & Appraisal services & & & \\
\hline & $\begin{array}{l}\text { Collecting data on students' progress to enable teachers } \\
\text { solve their academic problems }\end{array}$ & 2.34 & .969 & Ineffective \\
\hline & $\begin{array}{l}\text { Interpreting data on students' progress to identify a } \\
\text { student's area of learning difficulties }\end{array}$ & 2.45 & 1.013 & Ineffective \\
\hline & $\begin{array}{l}\text { Collating data on students' progress in other to ascertain } \\
\text { their areas of interest }\end{array}$ & 2.39 & 1.072 & Ineffective \\
\hline & Overall mean $=2.39$ & & & \\
\hline & Information services & & & \\
\hline & $\begin{array}{l}\text { Providing relevant information to students to enable them } \\
\text { make intelligent choices on their academics }\end{array}$ & 2.49 & .919 & Ineffective \\
\hline & $\begin{array}{l}\text { Providing current career information to students to enable } \\
\text { them plans for their career life }\end{array}$ & $2.55^{*}$ & 1.013 & Effective \\
\hline & Inform students about the approaches to study effectively & $2.60 *$ & 1.029 & Effective \\
\hline & Overall mean $=\mathbf{2 . 3 9}$ & & & \\
\hline & Counselling services & & & \\
\hline & Counselling students to develop their self-esteem & 2.49 & 1.114 & Ineffective \\
\hline & $\begin{array}{l}\text { Counselling students to develop their career and } \\
\text { vocational interest }\end{array}$ & 2.40 & 1.016 & Ineffective \\
\hline & $\begin{array}{l}\text { Counselling students to enhance their academics and } \\
\text { develop their appetite for reading }\end{array}$ & $2.53 *$ & 1.034 & Effective \\
\hline & Overall mean $=2.47$ & & & \\
\hline
\end{tabular}

* Significant mean $(\overline{\mathrm{X}} \geq 2.50)$

Result in Table 1 shows that respondents perceived school guidance services and counsellors to be effective in providing newly admitted students with orientation about the school to prepare them 
for the school system, providing orientation service to students enable understand the school community better and providing students with orientation needed to enjoy their relationship with peers at a mean score of $2.58,2.55$ and 254 respectively. In regards to appraisal services, respondents perceived guidance services and counsellors to be ineffective in collecting data on students' progress to enable teachers solve their academic problems, interpreting data on students' progress to identify a student's area of learning difficulties and collating data on students' progress in other to ascertain their areas of interest at means score of 2.34, 2.45 and 2.39 respectively.

In regard to information services, respondents perceived guidance services and counsellors to be ineffective in providing relevant information to students to enable them make intelligent choices on their academics at a mean score of 2.49 but effective on providing current career information to students to enable them plans for their career life and informing students about the approaches to study effectively at a mean score of 2.55 and 2.60 respectively. In regards to counselling services, respondents perceived guidance services and counsellors to be ineffective in developing students' self-esteem and counselling students to develop their career and vocational interest at means score of 2.49 and 2.40 respectively but rated their school guidance services to be effective in counselling students to enhance their academics and developing students' appetite for reading at a mean score of 2.53. The overall mean score is 2.56 for orientation services, 2.39 for appraisal services, 2.39 for information services and 2.47 for counselling services. Since only the overall mean on orientation service (2.56) is greater than the criterion mean of 2.50. Hence, the results showed that principals perceived school guidance services and counsellors to be effective in the provision of orientation services in secondary schools in Edo State but ineffective in others (appraisal, information and counselling services).

Hypothesis 1: There is no significant difference between rural and urban principals in their perception on the effectiveness of school guidance services in secondary schools in Ekpoma

Table 2: T-test analysis on school location differences in principals' perception on the effectiveness of school guidance services in secondary schools in Edo State

\begin{tabular}{|c|c|c|c|c|c|c|c|}
\hline Variables & $\begin{array}{l}\text { School } \\
\text { location }\end{array}$ & $\mathrm{N}=36$ & $\overline{\mathbf{X}}$ & S.D & t-cal. & $\begin{array}{l}\text { p- } \\
\text { value }\end{array}$ & Remark \\
\hline \multirow{2}{*}{$\begin{array}{l}\text { Orientation } \\
\text { services }\end{array}$} & Urban & 18 & 2.63 & .769 & \multirow[t]{2}{*}{$3.167^{*}$} & \multirow[t]{2}{*}{002} & \multirow{2}{*}{$\begin{array}{l}\text { Reject } \\
\text { hypothesis }\end{array}$} \\
\hline & Rural & 18 & 2.29 & .805 & & & \\
\hline \multirow{2}{*}{$\begin{array}{l}\text { Appraisal } \\
\text { services }\end{array}$} & Urban & 18 & 2.47 & .765 & \multirow[t]{2}{*}{$3.291^{*}$} & \multirow[t]{2}{*}{.001} & \multirow{2}{*}{$\begin{array}{l}\text { Reject } \\
\text { hypothesis }\end{array}$} \\
\hline & Rural & 18 & 2.13 & .715 & & & \\
\hline \multirow{2}{*}{$\begin{array}{l}\text { Information } \\
\text { services }\end{array}$} & Urban & 18 & 2.47 & .765 & \multirow[t]{2}{*}{$3.291 *$} & \multirow[t]{2}{*}{.001} & \multirow{2}{*}{$\begin{array}{l}\text { Reject } \\
\text { hypothesis }\end{array}$} \\
\hline & Rural & 18 & 2.13 & .715 & & & \\
\hline \multirow{2}{*}{$\begin{array}{l}\text { Counselling } \\
\text { services }\end{array}$} & Urban & 18 & 2.54 & .759 & \multirow[t]{2}{*}{$2.782 *$} & \multirow[t]{2}{*}{.006} & \multirow{2}{*}{$\begin{array}{l}\text { Reject } \\
\text { hypothesis }\end{array}$} \\
\hline & Rural & 18 & 2.25 & .729 & & & \\
\hline
\end{tabular}

* t-calculated is significant at 0.05 alpha level

Result in Table 2 showed that the calculated t-value of 3.167 for orientation service, 3.291 for appraisal service, 3.291 for information service and 2.782 for counseling service are all statistically significant $(\mathrm{p}<0.05)$. Therefore, the null hypothesis is rejected. This indicates that the hypotheses which states that there is no significant difference between male and female students in their perception on the effectiveness of school guidance services in secondary schools in Ekpoma is 
rejected. Therefore, this implies that principals' perception on the effectiveness of school guidance services in secondary schools in Ekpoma differed by school location.

\section{Discussion}

The results showed that principals perceived school guidance services and counsellors to be effective in the provision of orientation services in secondary schools in Edo State but ineffective in others (appraisal, information and counselling services). Perhaps, this outcome is due to the low moral and financial support for school guidance services by school administrators and the state government respectively. Furthermore, the dearth of qualified school guidance counselors in Edo State, Nigeria may also be responsible for the low effectiveness of school counsellors in schools. The result of this study disagrees with that of Wrenn (2002) that guidance and counseling services were effective in providing: alternatives in self-understanding and in the courses of action open to the counsellee, some degree of intervention with the situation in which the counsellee finds himself (or herself) and with "important others" in the counsellee's immediate life; leadership in developing a healthy psychological environment for. . clients, and finally, for the improvement of the, counselling process through constant individual self-criticism and (for some counsellors) extensive attention to improvement of process through research. Result also disagrees with the result of Nwoye (2003) school counsellors were effective in: organising orientation to help new students from primary to secondary school adjust to the new environment; defining and interpreting the objectives of the guidance programme to the principal, teachers, students, parents and members of the community; identifying guidance needs of students and keeping teachers informed of developments which may have bearing on classroom situations among others.

Result showed that there is a significant difference between rural and urban principals in their perception on the effectiveness of school guidance services (appraisal, information and counselling services) in secondary schools in Ekpoma. The provision of social amenities like electricity, good roads and pipe borne water which has increased migration of qualified manpower and resources in the urban areas may be responsible for this discrepancy. The result of this study is in agreement with that of Aluede and Imonikhe (2002) that although students could readily identify roles of the school counsellors, there was a lack of consensus between students from rural schools and those from urban schools on effectiveness of school counselling services. Furthermore result showed that school location predicts students' perception on school counselling services in Edo State.

The result concurs with that of Monteiro-Leitner, Asner-Self, Milde, Leitner, and Skelton (2006) that the perceptions of rural and urban school students towards counsellors and their various services in schools (e.g., consulting on referrals, individual/group Counseling) were very similar and significantly indifferent. The results agrees with that of Beesley (2004) that students were generally satisfied with the services of counsellors, but the degree of satisfaction varied by school location and depended on the specific service area provided by the school counsellor. Result supports that of Langford (2006) that the more highly the students regarded the responsibilities of the school counsellor in general, the more likely they were to report a willingness to collaborate with school counsellors in their future practice.

The result is in line with that that of Agi (2013) that students' perception of the effectiveness of school guidance services differed significantly by school location. Result corroborates that of 
Chireshe (2006) that majority of both school counsellors and students viewed the school guidance and counselling services as beneficial and school counsellors as effectively playing their role. The result of the study disagrees with that of Printah (2014) that most of the students are ignorant of the existence of such services which could be the major cause of high rates of delinquency, truancy, alcohol and drug abuse and teenage pregnancies. Students' perception of the effectiveness of school guidance services did not differ significantly by school location.

\section{Conclusion}

The importance of school guidance services within the school system cannot be overemphasized in schools. It can be concluded that principals' perceived that only orientation services among others - appraisal, information and counselling service was effectively provided in secondary schools in Edo State. Furthermore, school location had significant influence on principals' perception on the effectiveness of the school guidance.

\section{Recommendations}

The following are the recommendations made on the study:

1) The Federal Government of Nigeria, in conjunction with the Federal Ministry of Education should establish without delay, guidance and counselling units in all secondary schools in the nation as envisaged in the National Policy on Education. This should be made an essential part of the Universal Basic Education (UBE) programme.

2) Guidance counsellors in the secondary schools should realize that their guidance counselling approaches should be such that will enable them to meet the needs of learners in schools. For this to be achieved, school heads, teachers, parents and the government must also be actively involved in provided their support where necessary.

3) Trained counsellors should be posted in schools in the rural areas. This will enable them to carry out all guidance programmes effectively.

4) All necessary assistance towards the establishment and progress of a solid educational system should be given by the Federal, State and Local Governments. For example, funds should be made available for the provision of appraisal, information and counselling services in secondary schools.

\section{References}

[1] Abiri, J.O. (2006). Elements of evaluation measurement and statistical techniques in Education, Ilorin; University of Ilorin Library and Public Committee.

[2] Agi, C.W. (2013). Evaluation of the status of guidance services in secondary schools in Rivers State, Nigeria. Journal of Education and Practice. 4(23), 78-84

[3] Akinpelu, O.F. (2004). Appraisal of students; Tests and non-test devices. In A.I Idowu, Guidance and Counselling in Education. Ilorin; Indemac Publishing.

[4] Chireshe, R. (2006). An assessment of the effectiveness of school guidance and counselling services in Zimbabwean secondary schools. An unpublished project submitted in accordance with the requirements for the Degree of Doctor of Education in the subject Psychology of Education at the University of South Africa.

[5] Cobia, D. C. (2007). Developing an effective and accountable school counseling program. Upper Saddle River, NJ: Prentice Hall.

[6] Coleman, H. L. (2009). Handbook of school counseling. Mahwah, NJ: Lawrence Erlbaum. 
[7] Cooley, L. (2010). The power of groups: Solution-focused group counseling in schools. Thousand Oaks, CA: Corwin Press.

[8] Coy, D. R. (2004). Developmental guidance and counseling in today's schools. Alexandria, VA: National Association of Secondary Schools.

[9] Dimmitt, C., Carey, J. C., \& Hatch, T. (2007). Evidence-based school counseling: Making a difference with data-driven practices. Thousand Oaks, CA: Corwin Press.

[10] Erford, B. T. (2010). Group work in schools. Upper Saddle River, NJ: Prentice Hall.

[11] Erford, B. T. (2011). Transforming the school counseling profession. Upper Saddle River, NJ: Prentice Hall.

[12] Fall, K. A. (2011). Theoretical models of counseling and psychotherapy. Florence, KY: Taylor \& Francis.

[13] Federal Republic of Nigeria (2013). National Policy on Education (4th Edition). Abuja: NERDC Press.

[14] Gibson, R. L. (2008). Introduction to guidance and counseling. Upper Saddle River, NJ: Prentice Hall.

[15] Geshinde, S. A. (1991). Practicum in guidance and counselling. external studies programme university of Ibadan. Ibadan: Sako Sak Comm. Printers.

[16] Geshinde, S. A. (2000). Organisation and Administration of Guidance Services in Schools. External Studies Programme. University of Ibadan. Ibadan Sako Sak Comm. Printers.

[17] Gysbers, N. C. (2006). Developing and Managing your school guidance program. Washington, DC: American Counseling Association.

[18] Heyden, S. M. (2011). Counseling children and adolescents. Belmont, CA: Brooks/Cole.

[19] Hoose, W. H. (1973). Elementary school guidance, and counselling. A Composite View.

[20] Idowu, S. (1986). Basics of guidance, and counselling. Ibadan: Signal Educational Services Ltd.

[21] Idowu, S. (1989). Choosing and Managing Your Career, University Press Limited.

[22] Ipaye, I. (1986). Roles and functions of counselors in Nigerian schools. The Nigerian Journal of Guidance and Counselllng. 2 (1): 87-106.

[23] Kauchak. D. P. (2011). Introduction to teaching: Becoming a professional. Upper Saddle River, NJ: Prentice Hall.

[24] Kolo, F.D. (2001). Elements of psychological testing for Counsellings and psychologists Zaria Department of Education A.B.

[25] Makinde O., (1985). Fundamental of guidance and councelling London: Macmillian Publishing Ltd.

[26] Neukrug, R. C. (2011). Counseling theory and practice. Belmont, CA: Brooks/Cole.

[27] Lunenburg, F.C. (2010). School guidance and counseling services. Journal of Schooling, 1(1), 19.

[28] Mamman, A. M. (2002). Guidance and counselling for schools. (2nd Edition) Yok Paraclete Publishers. Oladele, J.O. (1985). Guidance and counselling; A functional approach Lagos; Johnlad enterprises.

[29] Ogunsanmi, J.O (2011). Awareness of teachers on the effectiveness of guidance and counselling services in primary schools in Nigeria. International Journal of Academic Research in Business and Social Sciences, 1, 176-183.

\footnotetext{
*Corresponding author.

E-mail address: bettyehigbor@gmail.com/akintoyosi123@yahoo.com
} 